\title{
The effects of reserpine and LHRH or salmon GnRH analogues on gonadotropin release, ovulation and spermiation in common carp (Cyprinus carpio L.)
}

\author{
M. SOKOLOWSKA, T. MIKOLAJCZYK, P. EPLER, R. E. PETER (*), W. \\ PIOTROWSKI $\left({ }^{* *}\right), K$. BIENIARZ \\ Department of lchthyobiology and Fisheries, Agricultural Academy \\ 30-149 Kraków-Mydlniki, Ambrosowa 6. Poland \\ (*) Department of Zoology, University of Alberta, \\ Edmonton. Alberta, Canada T6G $2 E 9$ \\ (**) Narutowicz Hospital, Kraków, Poland
}

Summary. The effects of reserpine (catecholamine depletor) and $\mathrm{LHRH}$ analogues on gonadotropin secretion, spermiation and ovulation of common carp were investigated Injections of reserpine alone at a dose of 1 or $7 \mathrm{mg} / \mathrm{kg}$ of body weight stimulated spermiation, and reserpine at a dose of $1 \mathrm{mg} / \mathrm{kg}$ of body weight in combination with (D-Arg ${ }^{6}$, Trp $\left.^{7}, \mathrm{Leu}^{8}, \mathrm{Pro}^{9}, \mathrm{NEt}\right)-\mathrm{LHRH}(\mathrm{s}-\mathrm{GnRH}-\mathrm{A})$ or with (D-Ala ${ }^{6}, \mathrm{Pro}^{9}$ )-LHRH $(\mathrm{LHRH}-\mathrm{A})$ at a dose of $50 \mu \mathrm{g} / \mathrm{kg}$ of body weight caused an increase of plasma gonadotropin levels, spermiation and ovulation in $80-90 \%$ of the females. Simultaneous injection of reserpine and $\mathrm{LHRH}$ analogues was as effective as injection of reserpine followed by injection of LHRH analogues $6 \mathrm{~h}$ later.

\section{Introduction.}

Recent studies have shown that in goldfish and some other teleosts dopamine acts as a gonadotropin release-inhibitory factor by modulating the action of gonadotropin-releasing hormone $(\mathrm{GnRH})$ (Peter et al., 1986). On this basis the use of dopamine antagonists in combination with analogues of $\mathrm{GnRH}$ has proven to be a very effective means of inducing ovulation or spermiation in goldfish (Chang and Peter, 1983 ; Chang et al., 1984 ; Sokolowska et al., 1984 ; 1985a, b; Peter et al., 1987), common carp (Billard et al., 1983; Lin et al., 1985b), silver carp (Lin et al., 1985b) coho salmon (Van der Kraak, 1984), African catfish (de Leeuw et al., 1985) and Chinese loach (Lin et al., 1985a, 1986). In studies on loach (Lin et al., 1986) and goldfish (Peter et al., 1986) it has also been demonstrated that drugs that block the synthesis of dopamine, or that generally inhibit the actions of catecholamines, also block the inhibitory action of dopamine, leading to potentiation of the actions of LHRH analogues (LHRH-A) on gonadotropin secretion. Reserpine, a drug which depletes catecholamines, has been shown to potentiate the effects of a LHRH-A on serum gonadotropin levels and ovulation in common carp and in loach kept at $20-28{ }^{\circ} \mathrm{C}$ 
(Lin et al., 1985b, 1986). Peter et al. (1985) found that salmon $\mathrm{GnRH}$ analogue (D-Arg ${ }^{6}, \operatorname{Trp}^{7}, \mathrm{Leu}^{8}, \mathrm{Pro}^{9} \mathrm{NEt}$ )-LHRH (sGnRH-A) was more potent than (D-Ala ${ }^{6}$, Pro $^{9}$ )- $\mathrm{LHRH}$ (LHRH-A) in stimulating GtH secretion in goldfish.

This paper investigates the effects of two different doses of reserpine in combination with sGnRH-A and LHRH-A on GtH release and spermiation in male carp kept at $12{ }^{\circ} \mathrm{C}$, as well as on $\mathrm{GtH}$ release and ovulation in female carp kept at $20^{\circ} \mathrm{C}$.

\section{Material and methods.}

Three experiments were carried out on common carp, Cyprinus carpio L., in 1985 and 1986. Groups and experimental treatments are summarized in table 1.

Experiment 1 : The effects of reserpine and $\mathrm{sGnRH}-\mathrm{A}$ on plasma $\mathrm{GtH}$ levels and spermiation in male carp. A total of 60 males (mean body weight $1.8 \mathrm{~kg}$ ) were divided into 6 groups and kept for 5 days in flow-through basins $(950 \mathrm{l})$, at the Department of Ichthyobiology and Fisheries (DIF), Agricultural Academy, Kraków, Poland. The fish were maintained at $12{ }^{\circ} \mathrm{C}$ on a natural photoperiod $(14 \mathrm{~L}: 10 \mathrm{D})$ in mid-April 1985.

Experiment 2: The effects of reserpine and sGnRH-A on serum $\mathrm{GtH}$ concentrations and ovulation in female carp. A total of 50 females (mean body weight $2.5 \mathrm{~kg}$ ) were divided into 5 groups (table 1) and kept for 5 days in flow-through basins (DIF) at $20^{\circ} \mathrm{C}$ under a natural photoperiod (16 L: $\left.8 \mathrm{D}\right)$ in mid-June 1985.

Experiment 3 : The effects of reserpine and LHRH-A on ovulation in female carp. A total of 30 females (mean body weight $5.0 \mathrm{~kg}$ ) were divided into 3 groups (table 1) and kept for 2 days in flow-through basins (4650-7250 I) at the Government Fish Farm, Lublin, Samokleski, Poland, at $20^{\circ} \mathrm{C}$ under a natural photoperiod (15 L : $9 \mathrm{D}$ ) in mid-May 1986.

Reserpine (Serpasil, CIBA) was purchased in a pharmacy. LHRH-A was purchased from Syndel Laboratoires, Vancouver, British Columbia, Canada. sGnRH-a was a gift from J. E. Rivier, The Clayton Foundation Laboratories for Peptide Biology, The Salk Institute San Diego, CA, USA.

Reserpine solution was injected intraperitoneally at a dose of 1 or $7 \mathrm{mg} / \mathrm{kg}$ of body weight. sGnRH-A or LHRH-A were made up in a vehicle of acidified $0.6 \%$ saline $(0.20 \mathrm{ml}$ of glacial acetic acid/liter $)$. Both analogues were injected intraperitoneally at a dose of $50 \mu \mathrm{g} / \mathrm{kg}$ of body weight.

Carp hypophysial homogenate (c.h.h.) was prepared just before use and injected intraperitoneally at a dose of $0.2 \mathrm{mg} / \mathrm{kg}$ and $0.8 \mathrm{mg} / \mathrm{kg}$ in two injections at an interval of $12 \mathrm{~h}$. Carp pituitary glands were collected in autumn from adult common carp of either sex.

Control groups were given acidified saline (PS). Blood samples were taken from fish in experiments 1 and 2 by puncturing the caudal vasculature with a heparinized 25-gauge needle attached to $1-\mathrm{ml}$ syringe. Blood samples were stored for a few minutes on ice and the plasma was then separated by centrifugation. The plasma samples were stored at $-20^{\circ} \mathrm{C}$ before shipment on dry 
TABLE 1

Experimental design using reserpine and $L H R H$ or salmon $G n R H$ analogues on gonadotropin release, ovulation and spermiation in common carp (Cyprinus carpio L.).

\begin{tabular}{|c|c|c|c|c|c|}
\hline \multirow{2}{*}{ Experiment group } & \multicolumn{3}{|c|}{ Treatment } & \multirow{2}{*}{$\begin{array}{l}\text { Blood } \\
\text { sampling } \\
\text { (hr after } \\
\text { 2nd inj.) }\end{array}$} & \multirow{2}{*}{$\begin{array}{l}\text { Checking of } \\
\text { ovulation or } \\
\text { spermiation } \\
\text { (hrs after } 2 \text { nd inj.) }\end{array}$} \\
\hline & & $\begin{array}{l}\text { 1st inj. } \\
(-12 \mathrm{~h})\end{array}$ & $\begin{array}{l}\text { 2nd inj. } \\
(0 \mathrm{~h})\end{array}$ & & \\
\hline 1 & $\begin{array}{l}\text { A } \\
B \\
C \\
D \\
E \\
\text { E }\end{array}$ & $\begin{array}{l}\text { PS } \\
\text { res. } 1 \mathrm{mg} / \mathrm{kg} \\
\text { res. } 7 \mathrm{mg} / \mathrm{kg} \\
\text { res. } 1 \mathrm{mg} / \mathrm{kg} \\
\text { res. } 7 \mathrm{mg} / \mathrm{kg} \\
\text { c.h.h. } \\
0.2 \mathrm{mg} / \mathrm{kg}\end{array}$ & $\begin{array}{l}\text { PS } \\
\text { PS } \\
\text { PS } \\
\text { sGnRH-A } \\
50 \mu g / k g \\
\text { sGnRH-A } \\
50 \mu g / \mathrm{kg} \\
\text { c.h.h. } \\
0.8 \mathrm{mg} / \mathrm{kg}\end{array}$ & $\begin{array}{r}-12,0,+12 \\
+24,+48\end{array}$ & $\begin{array}{l}-12,0,+12 \\
+24,+48\end{array}$ \\
\hline II & $\begin{array}{l}A \\
B \\
C \\
D \\
E\end{array}$ & $\begin{array}{l}\text { PS } \\
\text { res. } 1 \mathrm{mg} / \mathrm{kg} \\
\text { PS } \\
\text { res. } 1 \mathrm{mg} / \mathrm{kg} \\
\text { res. } 1 \mathrm{mg} / \mathrm{kg}\end{array}$ & $\begin{array}{l}\text { PS } \\
\text { PS } \\
\text { sGnRH-A } \\
50 \mu g / \mathrm{kg} \\
\text { res. } 1 \mathrm{mg} / \mathrm{kg} \\
\text { sGnRH-A } \\
50 \mu \mathrm{k} / \mathrm{kg}\end{array}$ & $\begin{array}{l}-12,0+12 \\
+24,+36\end{array}$ & $\begin{array}{l}+12,+24 \\
+36\end{array}$ \\
\hline III & $\begin{array}{l}1 \\
2\end{array}$ & $\begin{array}{l}(-6 \mathrm{~h}) \\
\text { res. } 1 \mathrm{mg} / \mathrm{kg} \\
-\end{array}$ & $\begin{array}{l}(\mathrm{O} \mathrm{h}) \\
\mathrm{LHRH}-\mathrm{A} \\
50 \mu \mathrm{gg} / \mathrm{kg} \\
\mathrm{res} .1 \mathrm{mg} / \mathrm{kg} \\
\mathrm{LHRH}-\mathrm{A} \\
50 \mu \mathrm{gg} / \mathrm{kg} \\
\text { PS }\end{array}$ & & $\begin{array}{l}+12,+16 \\
+18,+21\end{array}$ \\
\hline
\end{tabular}

ice to the University of Alberta, Edmonton, Canada, where GtH concentrations were measured by the radioimmunoassay (Peter et al., 1984). The volume of sperm was measured and ovulation checked by stripping at the time of bleeding (see table 1).

The Mann-Whitney U-test (two-tailed) was used to compare GtH concentrations and the volume of sperm between experimental and control groups. To compare the number of ovulated fish between the groups, Fisher's exact one-tailed test was used.

\section{Results.}

Experiment 1. - The effects of reserpine and sGnRH-A on plasma GtH levels and spermiation in male carp.

a) Gonadotropin concentrations (fig. 1). - Plasma GtH levels were significantly higher in all the experimental groups compared to the control group from 
the time of the second injection through to the end of the experiment. The highest $\mathrm{GtH}$ levels were found in fish injected with c.h.h. : starting at the 12-h sampling time the c.h.h. group had significantly higher plasma $\mathrm{GtH}$ levels compared to all the other experimental groups. In fish injected with the low or high dose of reserpine plus sGnRH-A in the second injection, plasma GtH levels at the 12, 24 and $48 \mathrm{~h}$ sampling times were significantly higher than in fish injected with reserpine alone.

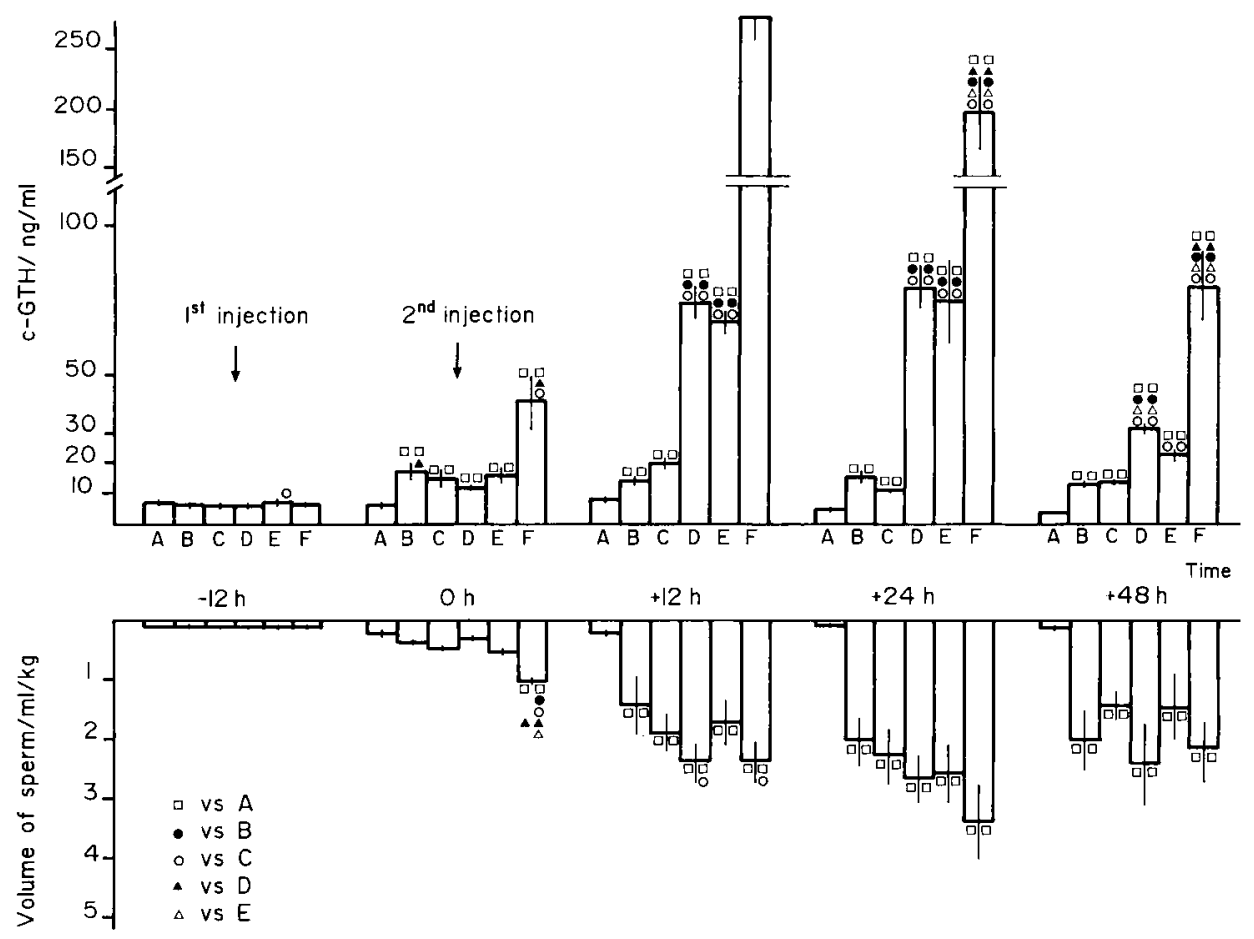

FIG. 1. - Changes in plasma GtH levels and volume of sperm following treatment of male carp with reserpine or reserpine in combination with $s G n R H-A$

Values are mean \pm SE. Significance levels : one symbol, $p<0.05$; two symbols, $p<0.01$

$1^{\text {st }}$ injection.

$2^{\text {nd }}$ injection

\begin{tabular}{llcl}
\hline A & PS & + & PS \\
B & Res $/ 1 \mathrm{mg} / \mathrm{kg} /$ & + & PS \\
C & Res $/ 7 \mathrm{mg} / \mathrm{kg} /$ & + & $\mathrm{PS}$ \\
D & Res $/ 1 \mathrm{mg} / \mathrm{kg} /$ & + & $\mathrm{sGnRH}-\mathrm{A} / 50 \mathrm{ug} / \mathrm{kg} /$ \\
E & Res $/ 7 \mathrm{mg} / \mathrm{kg} /$ & + & $\mathrm{sGnRH}-\mathrm{A} / 50 \mathrm{ug} / \mathrm{kg} /$ \\
F & c.h.h. $/ 0.2 \mathrm{mg} / \mathrm{kg} /$ & + & c.h.h. $/ 0.8 \mathrm{mg} / \mathrm{kg} /$
\end{tabular}


b) Volume of sperm (fig. 1). - The volume of sperm obtained from fish in the experimental groups were significantly higher than in the group injected with saline. There were no differences among the experimental groups, with the exception of time 0 (time of the second injection), when the volume of milt obtained from fish injected with c.h.h. was significantly higher than in all the other groups of fish. Maximal milt production in the experimental groups was detected at 12 and $24 \mathrm{~h}$ after the second injection $(2.37-3.42 \mathrm{ml} / \mathrm{kg})$.

Experiment 2. -The effect of reserpine and sGnRH-A on plasma $\mathrm{GtH}$ levels and ovulation in female carp (fig. 2).

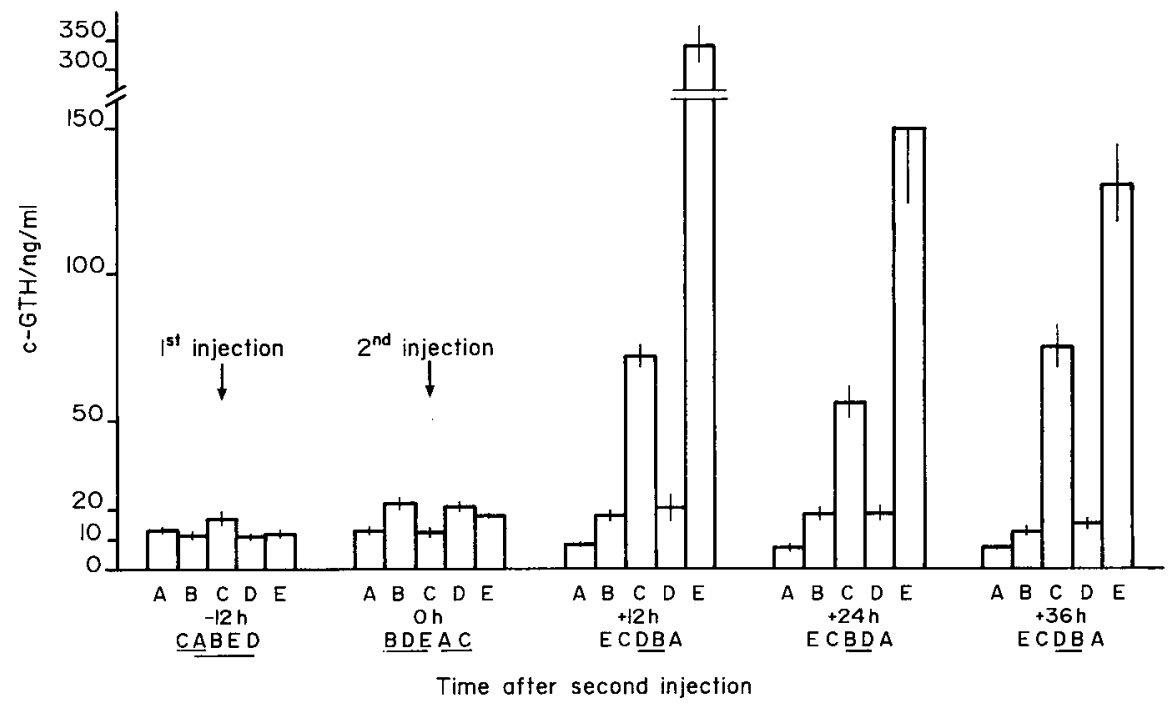

FIG. 2. - Changes in plasma GtH levels and ovulations in female carp injected with reserpine, $s G n R H-A$ or a combination of reserpine and $s G n R H-A$.

Values are mean \pm SE. Means which are not significantly different $(p<0.05)$ are underlined

$\mathrm{t}=20^{\circ} \mathrm{C}$
$1^{\text {st }}$ injection

\begin{tabular}{lllll}
\hline A & PS & + & $P S$ & $0 / 9$ \\
B & Res $/ 1 \mathrm{mg} / \mathrm{kg} /$ & + & $\mathrm{PS}$ & $0 / 9$ \\
C & $\mathrm{PS}$ & + & $\mathrm{sGnRH}-\mathrm{A} / 50 \mathrm{ug} / \mathrm{kg} /$ & $1 / 9$ \\
D & $\operatorname{Res} / 1 \mathrm{mg} / \mathrm{kg} /$ & + & $\operatorname{Res} / 1 \mathrm{mg} / \mathrm{kg} /$ & $0 / 9$ \\
E & $\operatorname{Res} / 1 \mathrm{mg} / \mathrm{kg} /$ & + & $\mathrm{sGnRH}-\mathrm{A} / 50 / \mathrm{ug} / \mathrm{kg}$ & $4 / 9$
\end{tabular}

Plasma GtH levels in fish in the experimental groups were significantly higher than in the saline-injected controls at 12,24 and $36 \mathrm{~h}$ after the second injection. The group receiving reserpine $(1 \mathrm{mg} / \mathrm{kg})$ plus $\mathrm{sGnRH}-\mathrm{A}(50 \mu \mathrm{g} / \mathrm{kg})$ had signi- 
ficantly higher $\mathrm{GtH}$ levels compared to each of the other experimental groups at the 12, 24 and 36-h sampling times. In this group four out of nine females were ovulated at the 24-h sampling time. In the group injected with sGnRH-A alone only one of nine females ovulated; plasma GtH levels in this group were significantly higher than in fish receiving reserpine alone. No ovulations were found in the group treated with reserpine alone.

Experiment 3. - The effects of reserpine and LHRH-A on ovulation in female carp.

In the group of fish injected with reserpine followed by LHRH-A 6 h later, ovulation was observed in nine out of ten females : three ovulated fish were found after $12 \mathrm{~h}$, an additional five at $16 \mathrm{~h}$ and the last one at $21 \mathrm{~h}$ after the second injection. In the group receiving reserpine plus $\mathrm{LHRH}-\mathrm{A}$, injected simultaneously, ovulation was observed in 8 out of 10 fish : five ovulated females were found at $18 \mathrm{~h}$ after the injection and the next three after $21 \mathrm{~h}$. There were no ovulated fish in the saline-injected group.

Females were stripped and the eggs artificially fertilized. The percentage of fertilization was 90 . After four days of incubation the percentage of hatching was 80 to 85 .

\section{Discussion.}

The present study indicates that injection of reserpine and sGnRH-A or LHRH-A into common carp is an effective means of stimulating gonadotropin secretion, leading to spermiation and ovulation. Spermiation could also be stimulated by reserpine alone. In our experiment conducted on male carp, the use of reserpine atone at a dose of 1 or $7 \mathrm{mg} / \mathrm{kg}$ of b.wt. or in combination with sGnRH-A $(50 \mu \mathrm{g} / \mathrm{kg})$ caused a statistically significant increase in the volume of sperm compared to saline-injected fish.

However, there were no significant differences in the volume of sperm between males injected with reserpine in combination with sGnRH-A and fish receiving c.h.h., except at time 0 (the time of the second injection), when the group given c.h.h. had a significantly higher volume of sperm than all other groups. It is possible that for $12 \mathrm{~h}$ after the first injection of reserpine the increased circulating $\mathrm{GtH}$ levels were not adequate to stimulate spermiation to the same level as injection of c.h.h., as suggested by analysis of $\mathrm{GtH}$ concentration. In the groups injected with reserpine alone $\mathrm{GtH}$ levels did not exceed $20 \mathrm{ng} / \mathrm{ml}$, whereas in males injected with the first dose of c.h.h. plasma GtH levels were twice as high. However analysis of $\mathrm{GtH}$ levels and volume of sperm at 12, 24 and $48 \mathrm{~h}$ after the second injection showed no significant differences in the volumes of sperm between groups receiving reserpine alone, reserpine with $s \mathrm{GnRH}-\mathrm{A}$, or c.h.h., in spite of the differences in plasma GtH levels between these groups. It is possible that in sexually mature males, at the time just before natural spawning (April), the injection of reserpine alone in the presence of the high endogenous content of 
$\mathrm{GnRH}$ at this time of the year (The Peptide Hormone Group, 1977) caused an increase in serum $\mathrm{GtH}$ sufficient to stimulate spermiation.

Lin et al. (1985b) used reserpine at a dose of $10 \mathrm{mg} / \mathrm{kg}$ of b.wt. plus LHRH -A to stimulate $\mathrm{GtH}$ release and ovulation in $60 \%$ of the female carp kept at $18.5-19.5^{\circ} \mathrm{C}$. The same treatment with reserpine and $\mathrm{LHRH}-\mathrm{A}$ at a temperature of $24-28{ }^{\circ} \mathrm{C}$ caused ovulation in $90 \%$ of the females. These results led the authors to conclude that temperature influences pituitary responsiveness to reserpine or to pimozide and LHRH-A in common carp. This is different from goldfish in which injection of pimozide plus LHRH-A stimulates a large increase in serum GtH levels and a low rate of ovulation in fish held at $12{ }^{\circ} \mathrm{C}$ (Chang and Peter, 1983).

In experiment 2, female common carp injected with reserpine $(1 \mathrm{mg} / \mathrm{kg}$ of b.wt.) plus sGnRH-A (50 $\mu \mathrm{g} / \mathrm{kg}$ of b.wt.) had very high plasma GtH levels, but only 4 out of 9 fish ovulated. It is unlikely that temperature accounted for the low rate of ovulation observed as the fish were held constant at $20^{\circ} \mathrm{C}$. However, a check of the state of the ovaries of the unovulated fish in the experiment showed that, at the time the experiment was performed (mid-June), almost a month after the time of natural spawning, the majority of the oocytes were undergoing resorption. Because of this, the experiment was repeated the following year at the beginning of May. Injection of reserpine $(1 \mathrm{mg} / \mathrm{kg}) 6 \mathrm{~h}$ prior to LHRH-A caused ovulation in 9 out of 10 females within $21 \mathrm{~h}$ after the second injection. Simultaneous administration of these two drugs stimulated ovulation in 8 out of 10 fish. A parallel experiment conducted on common carp at the same time using pimozide and LHRH-A or SGnRH-A/Bieniarz, unpublished data/ demonstrated a similar rate of ovulation.

The results show that for practical purposes not only specific dopamine antagonist, but also reserpine, a drug which causes depletion of catecholamines, may be useful in combination with $\mathrm{GnRH}$ analogues in stimulating spermiation and ovulation of cultured carp. In our study reserpine alone stimulated spermiation in carp, whereas Billard et al. (1983) demonstrated that pimozide (a dopamine antagonist) was not effective in inducing $\mathrm{GtH}$ release and spermiation in carp. This is noteworthy because reserpine is readily available. In addition, our results demonstrate that a high ovulation rate can be obtained when reserpine and LHRH-A are injected simultaneously, which is an advantage compared to the two injections required in the traditional techniques involving c.h.h., as it reduces fish handling and the stress connected with it.

Acknowledgement. - We wish to thank Miss Carol S. Nahorniak for doing the gonadotropin radioimmunoassays. The research was supported in part by a grant to R.E.P. from the Natural Sciences and Engineering Research Council of Canada.

Résumé. Les effets de la réserpine et d'analogues de LHRH ou de GnRH de saumon sur la décharge de gonadotropines, I'ovulation et la spermiation chez la carpe commune (Cyprinus carpio L.). 
Les effets de la réserpine (un inhibiteur de catécholamines) et d'analogues de LHRH sur la sécrétion de gonadotropines, la spermiation et l'ovulation ont été analysés chez la carpe commune. Des injections de réserpine seule à la dose de 1 ou $7 \mathrm{mg} / \mathrm{kg}$ de poids corporel stimulent la spermiation ; la réserpine, à la dose de $1 \mathrm{mg} / \mathrm{kg}$ de poids corporel combinée au (D-Arg ${ }^{6}, \operatorname{Trp}^{7}, \mathrm{Leu}^{8}, \mathrm{Pro}^{9}, \mathrm{NEt}$ )-LHRH (S-GnRH-A) ou au (D-Ala ${ }^{6}$, Pro $^{9}$ )-LHRH (LHRH-A), à la dose de $50 \mu \mathrm{g} / \mathrm{kg}$ de poids corporel, provoque une augmentation des niveaux de gonadotropines plasmatiques, la spermiation et l'ovulation de 80 à $90 \%$ des femelles. L'injection simultanée de réserpine et d'analogues de LHRH est aussi efficace que l'injection de réserpine suivie de celle d'analogues de LHRH 6 heures après.

\section{References}

BILLARD R., ALARGARSWAMI K., PETER R. E., BRETON B., 1983. Potentialisation par le pimozide des effets du LHRH-A sur la sécrétion gonadotrope hypophysaire, l'ovulation et la spermiation chez la Carpe commune (Cyprinus carpio). C. R. Acad. Sci. Paris, Sér. C, 296, $181-184$

CHANG J. P., PETER R. E., 1983. Effects of pimozide and Des $\mathrm{Gly}^{10}$-[D-Ala $\left.{ }^{6}\right]$ luteinizing hormone-releasing hormone ethylamide on serum gonadotropin concentrations, germinal vesicle migration and ovulation in female goldfish, Carassius auratus. Gen comp. Endocrinol., 52, 30-37.

CHANG J. P., PETER R. E., NAHORNIAK C. S., SOKOŁOWSKA M., 1984. Effects of catecholaminergic agonists and antagonists on serum gonadotropin concentrations and ovulation in goldfish : evidence for specificity of dopamine inhibition of gonadotropin secretion. Gen. comp. Endocrinol., 55, $351-360$.

DE LEEUW R., GOOS H. J. Th., RICHTER C. J. J., EDING E. H., 1985. Pimozide-LHRH-induced breeding of the African catfish Clarias gariepinus (Burchel). Aquaculture, 44, 295-302.

LIN H. R., PENG C., LU L. Z., ZHOU X. J., VAN DER KRAAK G., PETER R. E., 1985a. Induction of ovulation in the loach (Paramisgurnus dabryanus) using pimozide and (D-Ala ${ }^{6}$, Pro $^{9}-\mathrm{N}$ Ethylamide)-LHRH. Aquaculture, 46, 333-340.

LIN H. R., LIANG J. Y., PENG C., LI G. Y., LU L. Z., ZHOU Y. J., VAN DER KRAAK G., PETER R. E., 1985b. The effects of LHRH analogue and drugs which block the effects of dopamine on gonadotropin secretion and ovulation in fish cultured in China, 139-150. In R. BILLARD, J. MARCEL, Aquaculture of Cyprinids I.N.R.A. Publications, Paris, France, pp. 139-150.

LIN H. R., PENG C., VAN DER KRAAK G., PETER R. E., BRETON B., 1986. Effects of (D-Ala ${ }^{6}$, Pro $^{9}-\mathrm{NEt}$ )-LHRH and catecholaminergic drugs on gonadotropin secretion and ovulation in the Chinese loach (Paramisgurnus dabryanus). Gen. comp. Endocrinol., 64, 389-395.

(The) PEPTIDE HORMONE GROUP, 1977; A procedure for the radioimmuno-assay of LRH in the hypothalamus of the carp. Acta bioch. biophys. Sin., 9 (1), 105-110.

PETER R. E., NAHORNIAK C. S., CHANG J. P., CRIM L. W., 1984. Gonadotropin release from the pars distalis of goldfish Carassius auratus, transplanted beside the brain or into the brain ventricles: Additional evidence for gonadotropin release-inhibitor factory. Gen. comp Endocrinol., 55, 337-346.

PETER R. E., SOKO ŁOWSKA M., NAHORNIAK C. S., RIVIER J. E., VALE W. W., 1987. Comparison of (D-Arg $\left.{ }^{6}, \operatorname{Trp}^{7}, \mathrm{Leu}^{8}, \mathrm{Pro}^{9}, \mathrm{NEt}\right)$-luteinizing hormone-releasing hormone (sGnRH-A), and (D-Ala ${ }^{6}$, Pro $^{9}, \mathrm{NEt}$ )-luteinizing hormone-releasing hormone (LHRH-A), in combination with pimozide, in stimulating gonadotropin release and ovulation in the goldfish, Carassius auratus. Can. J. Zool., 65, 987-991.

PETER R. E., CHANG J. P., NAHORNIAK C. S., OMELJANIUK R. J., SOKOKOWSKA M., SHIH S.-H., BILLARD R., 1986. Interactions of catecholamines and $\mathrm{GnRH}$ in regulation of gonadotropin secretion in teleost fish. Rec. Prog. Horm. Res., 42, 513-548.

PETER R. E., NAHORNIAK C. S., SOKOŁOWSKA M., CHANG J. P., RIVIER J. E., VALE W. W., KING J. A., MILLAR R.P., 1985. Structure-activity relationships of mammalian, chicken and 
salmon gonadotropin releasing hormones in vivo in goldfish. Gen. comp. Endocrinol., 58 , $231-242$.

SOKOLOWSKA M., PETER R. E., NAHORNIAK C. S., PAN C. H., CHANG J. P., CRIM L. W., WEIL C., 1984. Induction of ovulation in goldfish, Carassius auratus, by pimozide and analogues of LH-RH. Aquaculture, 36, 77-83.

SOKOŁOWSKA M., PETER R. E., NAHORNIAK C. S., 1985a. The effect of different doses of pimozide and (D-Ala ${ }^{6}, \mathrm{Pro}^{9}-\mathrm{N}$ ethylamide)-LHRH (LHRH-A) on gonadotropin release and ovulation in female goldfish. Can. J. Zool., 63, 1252-1256

SOKOLOWSKA M., PETER R. E., NAHORNIAK C. S., CHANG J. P., 1985b. Seasonal effects of pimozide and des-Gly ${ }^{10}\left(\mathrm{D}-\mathrm{Al} \mathrm{a}^{6}\right) \mathrm{LHRH}$ ethylamide on gonadotropin secretion in goldfish. Gen. comp. Endocrinol., 57, 472-479.

VAN DER KRAAK G. J., 1984. Gonadotropin involvement in the control of oocyte maturation and ovulation in coho salmon (Oncorhynchus kisutch) : neuroendocrine control of gonadotropin secretion, effects on steroid production and properties of ovarian gonadotropin binding sites. Ph. D. Th., Univ. British Columbia, Vancouver, B. S. 1-178. 